\title{
Articles
}

WOJCIECH JÓZWIAK

DOI: $10.30858 /$ zer/83029

Institute of Agricultural and Food Economics

- National Research Institute

Warsaw

\section{THE EU COMMON AGRICULTURAL POLICY POST-2020 - CONTINUATION OF OR A BREAK FROM THE CURRENT PRACTICE}

\begin{abstract}
Central institutions of the European Union and academic circles in some of the EU countries have launched works that enable to outline the Common Agricultural Policy for the next EU financial perspective. Based on analyses of the official Polish and EU documents and studies prepared by academicians, the paper formulates a view that the Common Agricultural Policy in the next EU financial perspective will not be only a slightly corrected version of the policy implemented today. The circumstances force more profound changes, but a full break from the existing political practice should not be expected. The works on the development of the Common Agricultural Policy for the next financial perspective will, most probably, require the Polish Government to seek compromise solutions. However, it is impossible to predict the extent of these activities before getting to know the positions of other EU countries on the subject matter and without assessing their tendency to seek compromise solutions.
\end{abstract}

Keywords: post-2020 EU policy, EU agricultural policy, Polish agricultural policy, evolution of agricultural policy.

JEL codes: Q11, Q13, Q14, Q18, Q19. 


\section{Introduction}

The European Union countries have summarised their achievements in the first three years of the Common Agricultural Policy (CAP) pursued under the current financial perspective, and the EU centre, using these assessments, in 2016 started work to determine the shape of this policy for the next financial perspective, which will begin after 2020 .

In Poland, there was no wide-ranging debate on the desired shape of the future common agricultural policy, but the work in this regard, conducted at the government level, led to the adoption by the Polish Government - on 16 May 2017 - of a document entitled Common Agricultural Policy post-2020 - Polish priorities (Common..., 2017). This document expressed an opinion that subsequent reforms of the common agricultural policy allowed to solve various growing problems and were implemented with a "continuing support, strengthening the market orientation of EU agriculture and extending its public functions" (Common..., 2017). It has also been argued that existing "legal solutions leave room for further modernisation of CAP, in an evolutionary manner, without any fundamental changes in its structure" (Common..., 2017). Polish Government, however, plans to support only those new solutions that ensure a level playing field on the EU market and equal treatment of the EU citizens. This position is compliant with the position adopted by both chambers of the Polish Parliament. As regards agricultural matters, the government will seek to: align the level of direct payments for agricultural producers in all Member States; stabilise agricultural markets; undertake measures to improve the functioning of the food chain, including protection of small farms, and to introduce more effective production and price risk management instruments in the case of larger farms; simplify the CAP instruments and improve coordination of this policy with other EU policies (environment, cohesion, health, etc.). On nine pages of the quoted document, the criteria are set out which the Polish Government will follow while working on the CAP for the next financial perspective.

The presented article attempts to assess the possibility of implementing the above-mentioned government plans. What will happen, however, if this is not possible? Fortunately, the quoted document contains a statement that it reflects the views as of the day when it was drafted, and that the assessment criteria formulated therein may be updated at further stages of the process of creating the CAP for the next financial perspective.

\section{The future common policy will depend on changes in the structure of expenditure in the EU budget}

The view that future CAP will be created by slightly correcting the currently pursued policy has already been expressed in literature on the subject, inter alia, in Isermeyer's paper published in 2014 (Isermeyer, 2014). Isermeyer 
stresses that German society is interested not only in food production but also in rural biodiversity, water quality, animal welfare, and also in reducing income disparity of the farming population. Based on views formulated by agricultural producer organisations and also on his knowledge on financial policy adopted by German Federal Government, the author argues that basic principles underlying the currently pursued agricultural policy will remain in effect post-2020, although specific corrections will surely be made. He believes that a reform of CAP post-2020 has no chance of success if the EU budget allocation for this purpose is to be reduced. The current system of CAP financing should thus be maintained, however, some changes in the system of spending are advisable, namely:

- the first pillar of CAP should be gradually liquidated, and this process may initiate the process of deciding whether it is necessary to subsidise all farms and of formulating recommendations ensuring that production methods are consistent with public expectations, and accounting for a possibility that prices will rise;

- the second pillar should be transformed into a rural development programme, going beyond sectoral boundaries;

- it is advisable to establish a new pillar, focused on implementation of socially expected measures aimed at protecting public goods, mitigating adverse climate change and guaranteeing animal welfare; however only such measures that would be complementary to improvement in competitiveness of agriculture in the EU countries.

Several recent months have seen circumstances that may challenge the view that future CAP will be created through minor corrections of the currently pursued policy. The effects of the United Kingdom's leaving the European Union are not clear. Intensified migration from the Middle East and North African countries has become a problem, and solving this problem will require a costly immigration policy. The recently elected US President urges the EU countries to increase expenditure on defence. Moreover, the increasing populism, demonstrated during recent elections in several EU countries and threatening the democratic system, will force governments to allocate more funds for social policy.

The need for deeper changes in the amount and structure of the EU budget expenditure is pointed out in a document entitled Reflection paper on the future of EU finances, drawn up by the European Commission and published at the end of June 2017 (Reflection paper..., 2017). This paper indicates the sources of funds and describes how such funds should be spent, focusing however, on the latter issue.

It is stressed that funds must be spent in such a way as to achieve a high European added value. This concept includes not only positive effects of economic projects financed from the EU funds but it also provides for nurturing and sup- 
porting common EU values - democracy, freedom, rule of law, fundamental rights, equality, solidarity and sustainable development - to guarantee peace and prosperity of communities living in Member States. In addition, it provides for taking actions at the EU level, if this is more effective than actions at national, regional or local levels. The debate is to indicate the EU budget scenario accounting for the existing EU citizens' concerns and expectations arising from the new and complex situation.

The above-mentioned document contains five scenarios of EU budget expenditure for the next Financial Perspective:

- Scenario I reflects the currently implemented EU reform programme (EU-27), but the assumed share of expenditure for cohesion and agriculture policies is lower to ensure that new priorities can be financed, including: internal security, migration and defence policies, more robust control of the EU borders, etc.;

- Scenario II assumes a substantial cut in the EU budget, emphasising the functioning of the internal market (trans-European networks, customs duties, consumer protection, agencies), and it provides for a significant reduction in expenditure for the cohesion and agricultural policies;

- Scenario III provides for a possibility of budget increase to support joint actions and it assumes expenses the same as Scenario I as well as expenses for macro-economic stabilisation of the Eurozone (protection of investment, reinsurance of unemployment insurance, creation of a fund to finance the effects of natural disasters - rainy day fund);

- Scenario IV means lower budgetary receipts, introduction of taxes (ecological, on financial transactions, etc.), limited expenditure for the cohesion policy and the common agricultural policy, with focus on priorities maximising the European added value, inter alia, on developing new forms of transport and of electricity generation and transmission, also called smart transport and smart energy networks;

- Scenario V assumes: a significantly larger budget (its reform goes beyond the assumptions of Scenario IV), increased own contributions of Member States, and significant additional financing of new priorities with very high European added value and external actions, as well as a larger amount for pursuing the common agricultural policy.

It follows from the above that all four scenarios assume reduced expenditure for implementing the Common Agricultural Policy. In the justification of such a proposal it is pointed out that in result of the existing policy, EU residents have access to high-quality food at affordable prices. Prices of food produced in the EU are similar to those on the global market, and thus a significant part of such food can be exported. However, huge differences in the development level of agriculture exist, which diversifies farm income. Despite direct payments, the income of small farms as well as farms with unfavourable soil and climate conditions and farms operating in sub-mountainous and mountainous areas is 
insufficient. To make things worse, in several rural areas there are no alternative sources of income. This poses a risk of growing social exclusion with all its negative consequences on one hand, and on the other hand emigration leading to succession of undesirable vegetation on hitherto agricultural areas. Reducing the EU budget allocation for the common agricultural policy ought not therefore to deteriorate the economic situation of holders of small farms and those functioning in less-favoured areas, on the contrary - the new budget should improve their situation by correcting the level of direct payments.

Agricultural land occupies almost half of the EU area, and thus agricultural producers have a significant impact on protecting natural resources - soil, water, air, biodiversity, climate and landscape. Small farms and those functioning in less-favoured areas occupy a smaller part of this area, and therefore also larger farms should have access to some form of aid, as direct payments are conditional upon meeting specific requirements to preserve or improve the quality of natural resources. Recent events have shown that frequently funds from the Union budget had to be used for ad hoc support in emergency situations (e.g. embargo on the import of certain agricultural products to Russia). This shows that funds allocated for the future common agricultural policy should first of all strengthen the tools aimed at reducing the natural and price risks, to which all farms are exposed.

Support enjoyed by farms in the EU countries has a positive impact on social and economic development of rural areas. Future lower aid for agricultural producers will thus require a different way of financing this development. Funds for this purpose will most likely be provided under the economic, social and territorial cohesion policy.

A more precise description of the aforementioned scenarios confirms the above argument. In Scenario I, expenditure on the common agricultural policy is, to a greater extent than currently, to support small farms situated in mountainous areas and in sparsely populated areas. All farms will also receive support aimed at reducing risks, and rural development will be supported by funds allocated for investment in agri-environmental measures. Support for farms assumed under Scenario II is the same as in Scenario I, except that rural areas will not receive support for investment projects related to agri-environmental measures. Expenditure for the common agricultural policy foreseen in Scenario III is identical as in Scenario I. Also Scenario IV assumes reduction of direct payment and it focuses on small farms and on farms situated in mountainous and in sparsely populated areas, and moreover it is concentrated on agricultural activities mitigating the adverse impact of agricultural production on the environment and on climate change. In addition, all farms will receive support aimed at reducing risks.

Only Scenario V assumes increased expenditure from the EU budget for the agricultural policy. 
Not only funds spent on the Common Agricultural Policy but also those allocated for the cohesion policy are important for agriculture as part of the latter currently indirectly supports the desired transformation taking place in rural areas. From the quoted document it appears that these funds will also most likely be reduced in the next financial perspective, and this will apply to all five analysed scenarios. It is assumed that the reduced scope of the cohesion policy in Scenarios I-IV will be accompanied by economic, social and territorial cohesion policy with focus on projects aimed at reducing the scale of social exclusion, unemployment, greenhouse gas emissions and adverse ecological phenomena. However, in Scenario I less support is foreseen for investment projects implemented in the regions, which will force an increase in the level of national co-financing of such projects. Scenario II assumes that support under economic, social and territorial cohesion policy will be received only by Member States covered by the cohesion policy and by measures for cross-border cooperation. Scenario III assumes expenditure the same as Scenario I, while Scenario IV assumes that the economic, social and territorial cohesion policy will cover only the poorer regions and projects for cross-border cooperation.

The assumptions of Scenario V differ from those presented above. It is assumed that the economic, social and territorial cohesion policy will aim to strengthen territorial cooperation, social dimension (e.g., interests of children) and urban dimension (e.g., making use of knowledge about the leading role of urban agglomerations in economic development).

\section{The future common agricultural policy may also depend on consumers' opinions about the currently pursued policy}

Each EU resident is also a consumer of food produced within the Community, and as such has own opinion about such food, and sometimes also about related topics, such as agriculture and agricultural policy. Consumers' opinions may thus affect the choice of scenario for future budgetary expenditure of the Union - not necessarily one of the five scenarios presented above, which may indirectly determine the shape of future Common Agricultural Policy. These opinionsare presented in a paper published in 2016 by two Dutch authors Fresco and Poppe (2016). This paper is a kind of vision, but it has solid grounds in results of scientific research, as the authors made use of 29 detailed studies.

Fresco and Poppe are convinced that some opinions on the common agricultural policy and related issues are mistaken.

According to Fresco and Poppe, a quite common opinion that EU agriculture is undergoing a crisis comparable to those of 1880s and 1930s is unacceptable. Media often inform that farms are being sold, and statistics that the number of farms is declining. The reality, however, is different. Aggregate agricultural income in the EU countries has risen by about $1 / 5$ since 2005 , and high prices 
of land show that investing in agriculture makes sense. Only the situation of agricultural producers who lease land is disadvantageous, but it is young people who want to make their living from farming who are most disadvantaged.

Agricultural producers need to increase areas of their farms to keep real income at least at an unchanged level, as only investment increases the income at a rate similar to the growth rate of income parity. Therefore, land is being purchased from those agricultural producers who failed to stay in the market. As a result farms cultivating 50 ha of tomatoes, rearing 2,000 cows or conducting field production on 2,000 ha are no longer exceptional, and in several new EU countries there are even larger farms. Thus, agriculture keeps functioning but its shape is constantly changing.

Other critics of the current common agricultural policy underline the organisational weakness not only of agriculture but also of other links in the food chain. They refer to scandals related to poor food quality, caused by fraud or human errors. Allegedly only Spanish olive oil, Austrian wine, Belgian and French poultry, Dutch horse-meat and British beef avoided any such criticism close to scandal.

EU residents are also concerned about environmental losses caused mainly by: large agrochemical inputs, veterinary medicines, use of natural fertilisers which emit unbearable odour, and ignoring effects of adverse climate change caused by greenhouse gas emissions.

The above-quoted authors stress, however, that a breakthrough in food production was possible thanks to "industrialisation". In the European Union, there is no famine and food is cheaper (in the European Union, share of expenditure of households for this purpose is currently lower by $2 / 3$ than in the mid- $20^{\text {th }}$ century) and safer. Moreover, changes in the food chain led to: making the supply independent of local resources, broadening food market offer, and improving health of EU residents.

It is also difficult to agree with the view that international trade in food is harmful. However, some see the Union as an importer of soybean from South America, fish from Asia and tropical products from Africa, which, they claim, results in environmental problems in these regions, such as salinisation and soil erosion. There are also people who perceive international trade as a kind of land grabbing, harmful to development of those parts of the world. There is a third group of critics who point to the senselessness of exporting European red meat and poultry meat, as this puts a great burden on the natural environment in Europe. From the above views, we may conclude that the Union should pursue a policy of food self-sufficiency.

Yet, for many years the Union has been a net exporter of food, about 1/4 of food produced by the Community is exported. Exported is food of the highest quality and it is intended for middle class people in almost all countries of the world. On the other hand, the EU imports mainly feeds and products produced 
in tropical areas, which in turn supports economic development of Asian, African and Latin American countries.

The Union also makes a specific contribution fostering development of agriculture in many other regions of the world, by exporting seeds and other means of production and by providing specialised services.

Also the environmental burden caused by international food trade is a source of misunderstandings. Carbon emissions from transport are, in fact, very low when compared to emissions during food production, storage, refrigeration, etc. Besides, the import of goods produced by efficiently operating producers or in winter causes less environmental burden than inefficient local production and storage of goods produced.

Other critics claim that common agricultural policy is expensive and leads to overproduction. It is true that the share of EU budget expenditure allocated for the Common Agricultural Policy equals nearly 40\%, while the share of expenditure for other important objectives - such as defence and social policies, development of research or education - is significantly lower. However, those critics forget that individual Member States allocate large amounts for said purposes from their own budgets, and only small amounts for the agricultural policy. Also, it is ignored that common agricultural policy has contributed greatly to environment and landscape protection, because - as already mentioned - each agricultural producer using aid must comply with relevant crosscompliance principles.

On the other hand, it is important that climate change, consisting in increased air temperatures, caused intensified extreme weather phenomena, such as flood, drought and hurricanes, as well as spread of previously unknown diseases of plants and animals, not only reducing agricultural productivity but also increasing fluctuations in supply of agricultural products. Therefore, despite the progress achieved on a global scale, there are still about three billion people who suffer from famine or malnutrition. It is estimated that Earth could feed about 10 billion people, provided however that we have a rational impact on: weather, water resources, soil fertility, and the spread of diseases and pests.

The European Union has a greater percentage of good quality soils than any other areas of the world. It has also sufficient water resources and favourable climate. Besides, agricultural producers and food industry managers have at their disposal sophisticated technologies and they encourage innovation. The Union can, therefore, provide countries of other regions of the world with food that they lack and with proven food production technologies.

There is one more issue to be solved. On a global scale, about 1.5 billion people suffer from obesity, mainly in rich countries. The relations between nutrition and health are well known, and it is also known that some chronic diseases (diabetes type 2, cardiovascular diseases, some types of cancer) are associated with food we eat. 
An analysis of negative opinions on the current common agricultural policy and related issues indicates that such opinions are not always fully objective. The critics, however, point out that while pursued agricultural policy provides consumers with cheap food, and agricultural producers who prove themselves on the market with decent income, it is at the same time harmful for the climate, environment, landscape, and sometimes also for food quality.

Therefore, the common agricultural policy must be replaced with a new one, referred to by the above-quoted authors as common agricultural and food policy $^{1}$. To accept such a policy would require decision-makers to recognise that protecting the environment and consumer interests is as important as the interests of farming community and also that all links in the food chain (agriculture, processing of raw materials of agricultural origin, trade in food, manufacturers of means of production for agriculture) are inseparable parts of one whole, i.e. food economy.

The said authors formulate five objectives of the common agricultural and food policy. In the first place, they agrue that the diet of European Union citizens should contain fewer calories and be more balanced in terms of its components. Thus, it will surely be healthier, and it will indirectly contribute to mitigating adverse climate changes. A basic step in implementing this plan is to introduce the concept of real food production costs, taking into account first of all the cost of carbon dioxide emissions along the food chain, which means that this obligation should also apply to larger farms.

Nevertheless, a rise in food prices will not solve all problems connected with the diet. To this end, governments and non-governmental institutions should use other instruments, such as education and advice.

The second argument involved in developing the common agricultural and food policy refers to the first one as well as to the decisions taken at the climate summit in Paris in December 2015, which pointed to the legitimacy of amending the common agricultural policy. Of course, food security should be guaranteed, which does not imply that food production and consumption cannot contribute to reducing the speed of climate change. Carbon emissions are limited, for example, when farms use natural organic fertilisers (manure, so called green fertilisers, appropriately treated straw, etc.). Greenhouse gas emissions are also limited by indoor rather than free range rearing, which allows to solve the problem of faeces disposal. These examples show that trading in carbon emissions by farms may also contribute (like ETS in the industry) to the global ecosystem.

The third argument refers to practical achievements of several trade companies and companies processing raw materials of agricultural origin. Those

\footnotetext{
${ }^{1}$ The description of this policy suggests that it should rather be called the common food and environmental policy.
} 
companies have taken measures to mitigate adverse climate and environmental change, by encouraging agricultural producers to behave in a more eco-friendly manner and by launching a system to monitor their achievements. Some of these solutions are going even further than the government regulations. Other big companies of the food chain promised their shareholders and the public to launch carbon-neutral production processes. Measures of this kind allow private companies to strengthen their brand and to meet consumers' expectations, enhancing moreover the EU and governments' efforts focused on safe food production in a way least threatening for the environment and least affecting climate change, thus shaping food prices taking into account all the costs of food production.

The fourth argument has been probably formulated prematurely. It assumes that using information collected thanks to development of communication technologies will be an important way to reduce the environmental impact of pesticide inputs, mineral fertilisers and burning energy carriers in the agricultural production process. Some agricultural producers have been using such information for some time already, for example, by using the so-called precision farming equipment. However, it is doubtful if by the beginning of 2020s, developing communications technologies will allow local authorities to track, on-going basis, the reasons for changes in water quality, biodiversity or landscape, in such a way so as to enable an appropriate response to these phenomena. In fact, we must be aware that in the next financial perspective only some agricultural producers in the EU countries will have precision farming equipment.

The fifth and last argument taken into account by the quoted authors in formulating the proposed common agricultural and food policy post-2020 refers to adapting innovation in food industry, namely doing business in a form of networks or platforms (examples are Airnbnb and Uber). However, experience has taught us that the will of agricultural producers to associate, for example in groups or organisations, is growing too slowly for the above-mentioned innovative but still not sufficiently proven organisational forms to come into being in the food sector post-2020.

Fresco and Poppe conclude that the majority of the EU public is not satisfied with the currently pursued common agricultural policy, due to, inter alia, too imprecise definition and excessive simplification of this policy. As we know, currently it has two pillars. The first one, through direct payments, supplies farm income and guarantees market stability for farms. Agricultural producers have access to such aid if they take a certain number of environmental measures. The second pillar supports rural development and fosters innovation, is aimed at protecting nature, has positive impact on biodiversity, and strengthens the competitive position of farms.

In order to meet requirements of the EU taxpayers, the common agricul- 
tural policy should therefore be transformed into the common agricultural and food policy. In other words, it is necessary to change the way of thinking. Such a policy scenario assumes that current common agricultural policy will be transformed into three pillars with two new pillars added. This will simplify intervention logic as a result of defining the pillars in a precise manner.

Pillars of the common agricultural and food policy would include: A - support for agriculture producers' income and reduction of risk for EU residents food security; $\mathrm{B}$ - public issues and ecosystem services, which are not taken into account in market processes; $\mathrm{C}$ - support for innovation fostering rural development and improving life quality for local residents; D - food and consumer policy addressed to consumers as well as retail and agri-food industry, and focused on promoting a healthier diet (this measure would bring progress in terms of human health reducing at the same time the pressure of the entire food chain on climate); and $\mathrm{E}$ - monitoring and research allowing to correct the new policy based on the knowledge of its effects.

Fresco and Poppe are convinced that replacing the common agricultural policy with the common agricultural and food policy will lead to a more sustainable food production system. Even if we ignored some of the above assumptions contained in the proposed policy scenario, which are not possible to implement in a short term, the new policy would allow for maintaining the current sense of food security, ensuring at the same time access of EU residents to safe food and protecting interests of farming population at least at the current level. On the other hand, such a policy would enable to solve more effectively the problem of growing obesity, reducing at the same time food losses and consequently the adverse changes in climate, biodiversity and landscape.

Implementing this agricultural policy scenario for the next financial perspective would, naturally, result in a rise in food prices. This policy should, therefore, be formulated in a way ensuring that the price increase is gradual. Then, the higher living costs for citizens, resulting from the rise in food prices, could be compensated by lower taxes and reduced insurance rates due to lower costs of health care. The higher food prices would also reduce the costs of long-distance transport of food and would result in increased interest in organic food, that is, food produced from raw materials acquired by organic methods. However, we should expect that export of food produced in the EU countries will be limited.

\section{Summary}

Currently, the shape of common agricultural policy to be pursued in the next EU financial perspective is under development. The position of the Polish Government on this matter is to seek the following: aligned level of direct payments to agricultural producers in the Member States; stabilisation of agricultural markets; measures to improve the food chain functioning, based mainly on protect- 
ing the interests of small farms; introduction of more effective instruments to mitigate the risk to functioning of larger farms; real simplification of the common agricultural policy instruments; and better coordination of this policy with other EU policies (cohesion, environment, health, etc.).

The amount of funds to be allocated for the common agricultural policy is important, as such amount will determine the scope of this policy. An official EU reflection paper on the future budget contains a concise characteristic of five budget scenarios, four of which envisage reduced expenses for common agricultural policy and for cohesion policy, which has also partially supported rural development thus far. This is caused by a need to finance new priorities, namely improved internal security, and more active migration, defence, social, environmental and other policies.

It is assumed that future common agricultural policy will recognise, to a greater extent than currently, economic interests not only of small farms, as the Polish Government want, but also of those in mountainous areas and in sparsely populated areas. All farms would also receive support to reduce the risk, thus stabilisation of agricultural markets would be reinforced - a solution also sought by the Polish Government. Beneficiaries of such support would be, naturally, obliged to implement appropriate environmental measures, just as they are now. However, farms would lose support for implementing investment projects. This would limit the possibility of economic expansion of mediumsized agricultural enterprises and, consequently, would reduce the growth in the number of competitive farms in Poland, which started after the EU accession (Józwiak, 2014; Kagan, 2016).

Currently, the support for farms in the EU countries has an indirect positive impact on rural areas' social and economic development. Lower aid for agricultural producers in the future will thus require another way to finance such development. Most probably, this will be funds for economic, social and territorial cohesion policy, which, however, will highlight projects to reduce such phenomena as social exclusion, unemployment, greenhouse gas emissions, and adverse ecological phenomena.

The first and the third scenario, assuming reduced budgetary allocation for agricultural and cohesion policies, also provides for lower support for investment in regions, which will force an increased level of national co-financing. Therefore, this is an attempt to renationalise some EU activities, which so far have been joint activities. The second scenario envisages reduced scope not only of common agricultural and cohesion policies, but also of other common policies, putting emphasis only on efficient EU market functioning. The fourth scenario contains the assumption that the common economic, social and territorial cohesion policy will cover only poorer regions, and this could be beneficial for most rural areas in Poland. This scenario, however, highlights the priorities to maximise European added value, which includes not only the effects of 
economic activities undertaken, but also care for the common EU values. It is unknown how the latter will translate into access to EU budget funds, as recent Polish efforts have provoked controversy in central EU institutions and in some Community countries.

Only the fifth scenario, outlining the framework of a EU-wide debate on the EU budget in the next financial perspective, envisages an increase in the EU budget allocated for the agricultural policy. This scenario, however, refers to the concept of the European Union federalisation, which certainly is not in accordance with the policy currently pursued in Poland.

Then, perhabs we should consider one more scenario, for example that outlined by Fresco and Poppe? According to this scenario, environmental protection and consumer interests are as important as the interests of farming community. Thus we need to depart from the currently pursued agricultural policy. In developing policy under this scenario, it would be important to reject the argument underlying all five above-described scenarios, namely that food must be cheap, and to adopt an assumption that the cost of carbon emissions along the food chain should be accounted for in calculation of food production costs. This means that such an obligation should also cover farms, at least larger ones. Such an action would allow to maintain the existing achievements of the common agricultural policy, and in addition it would address such serious problems that need to be solved as: growing obesity and related diseases, need to reduce food losses, and consequently reducing more effectively adverse change in climate, biodiversity, landscape, etc.

An advantage of the currently pursued common agricultural policy is that prices of food produced in the EU countries are similar to the global prices. Agricultural policy based on the scenario proposed by Fresco and Poppe would increase such prices, which would have a negative impact on the EU balance of food trade. Worse still, the possibilities of producing food in the European Union would not be used in full, to the detriment of the food balance on a global scale.

Any speculations on the possibility of aligning the level of direct payments to agricultural producers in Member States and on the possibility of simplifying the common agricultural policy are premature. The above possibly applies also to the manner and extent of coordination of this policy with other EU policies. The latter will be, in fact, developed in parallel to the common agricultural policy.

On the grounds of the above analysis, it can be concluded that the Common Agricultural Policy in the next financial perspective will be not just a slightly revised version of the currently pursued policy. Current circumstances call for major amendments, but we cannot expect a full break from the current practice. Work on formulating the common agricultural policy for the next financial perspective will most likely require from Poland to seek compromise solutions, and 
thus concessions. Predicting the scope of these activities is, however, impossible before learning what are the positions of other Member States on the issue, and without assessing their willingness to reach a compromise. 


\section{References}

Common agricultural policy post-2020 - Polish priorities (2017). Document adopted by the Council of Ministers on 16 May 2017, Ministry of Agriculture and Rural Development. Typescript.

Fresco, L.O., Poppe, K.J. (2016). Towards a Common Agricultural and Food Policy. Wageningen: Wageningen University\&Research.

Isermeyer, F. (2014). Kunftige Anforderungen an die Landwirtschaft-Schlussfolgrungen für die Agrarpolityk. Thünen Working Paper 30, Johann Heinrich von Thünen-Institut, Bundesforscgsinstiitut für landliche Raum, Wald und Fischerei.

Józwiak, W. (ed.). (2014). Development of national agricultural enterprises of natural persons in the light of the "spiral of growth" idea. Multi-annual Programme 2011-2014, no. 113, Warsaw: IAFE-NRI.

Kagan, A. (2016). Selected legal determinants of competitiveness of large-scale agricultural enterprises. Warsaw: IAFE-NRI .

Reflection paper on the future of EU finances (2017). European Commission. COM (2017) 358 of 28 June 2017, Brussels. Retreved from: https://ec.europa.eu/ Poland/news/170628_finances_pl (2017) (access date: 29.06.2017). 
WOJCIECH JÓZWIAK

Instytut Ekonomiki Rolnictwa i Gospodarki Żywnościowej

- Państwowy Instytut Badawczy

Warszawa

\title{
WSPÓLNA UNIJNA POLITYKA ROLNA PO 2020 ROKU - KONTYNUACJA OBECNEJ PRAKTYKI CZY ZERWANIE Z NIĄ
}

\begin{abstract}
Abstrakt
Centralne instytucje Unii Europejskiej i środowiska naukowe w niektórych krajach unijnych rozpoczęły prace, które pozwalaja wstepnie zarysować kształt wspólnej polityki rolnej na kolejna unijna perspektywe finansowa. Na podstawie analizy oficjalnych dokumentów polskich $i$ unijnych oraz opracowań powstałych $w$ środowiskach naukowych $w$ artykule sformułowany zostat poglad, że wspólna polityka rolna w nastepnej unijnej perspektywie finansowej nie będzie tylko nieco skorygowana wersja polityki realizowanej obecnie. Okoliczności wymuszaja bowiem wprowadzenie głębszych zmian, ale nie należy oczekiwać całkowitego zerwania z dotychczasowa praktyka. Prace nad sformułowaniem wspólnej polityki rolnej na nastepna perspektywe finansowa będa najprawdopodobniej wymagać od polskiego rzadu szukania rozwiazań kompromisowych, a więc także ustepstw. Przewidywanie zakresu tych działań jest jednak niemożliwe przed poznaniem stanowisk innych krajów ugrupowania unijnego w przedmiotowej sprawie i bez oceny ich skłonności do kompromisu.
\end{abstract}

Słowa kluczowe: polityka unijna po 2020 roku, unijna polityka rolna, polska polityka rolna, ewolucja polityki rolnej.

Accepted for print: 16.10.2017.

Unless stated otherwise all the materials on the website are available under the Creative Commons Attribution 3.0 Poland license. Some rights reserved to the Institute of Agricultural and Food Economics - National Research Institute.

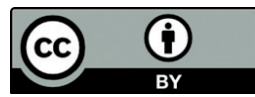

